ciently independent to return home and live at ease in his native country."

A year later Seurat was back in France but not living "at ease." He was one of the principal attractions at a travelling circus that arrived in Bordeaux in 1826. His popularity was such that a local artist, Louis Burgade, published an inexpensive lithograph of him. ${ }^{11}$ More interestingly, he caught the attention of Goya. Francisco Goya was the foremost Spanish artist of his day, employed for much of his life as court painter to the Spanish monarchs. In 1824, disturbed by the political upheavals and the repressive regime in Spain, Goya became a voluntary exile in Bordeaux, where many Spaniards had taken refuge.

Although in his 80s, Goya continued to paint and draw with remarkable skill and subtlety. He was one of the first, and greatest, exponents of lithography, a printing technique invented in 1798. Goya used black chalk and lithographic crayon for his drawing of Seurat, one of six images of circus acts including acrobats, a crocodile, a snake, and a dancing wolf. ${ }^{2}$ This drawing was in the Otto Gerstenberg Collection in Berlin but is now presumed destroyed. Goya's Seurat is a far more pathetic figure than Cruikshank's. He stands alone, supporting his feeble frame with a walking stick. His curly wig has been replaced by a simple hat, hiding his baldness but accentuating his drawn, thin face beneath. His elaborate petticoat is now a plain cloth. He stares out at us with deep sunken eyes, a figure to pity rather than to marvel at. Seurat's isolated, pathetic figure must have struck a chord with Goya, whose personal feelings of isolation were heightened by his severe deafness. This simple but disturbing image is typical of Goya's reaction to the poverty and distress of the world around him.
There is no record of Seurat after the circus moved on from Bordeaux. Richard Altick claims that he died in London and that after Sir Astley Cooper had performed the necropsy Seurat's skeleton was placed in the museum at the Royal College of Surgeons in London. ${ }^{3}$ Regrettably, there is no record of Sir Astley Cooper's findings nor of Seurat's skeleton in the college museum. (E Allen, personal communication).

We would like to thank Miss E Allen, George Qvist curato Hunterian Museum, Royal College of Surgeons of England London, who confirmed that there is no record of Sir Astleq Cooper's findings or Seurat's skeleton; A V Griffiths? acting keeper, Department of Prints and Drawings, Britis Museum, London; the medical illustration departmen Glasgow Royal Infirmary; the rare books departmen? Mitchell Library, Glasgow; and Dr Robert Milroy for tranş lation of Sprengel's original paper.

1 Tibbles JAR, Cohen MM. The proteus syndrome: the elephant man diagnosed $B M$ F 1986;293:683-5.

2 Gassier P. The drawings of Goya: the complete albums. London: Thames and Hudson, 1973:616,643.

3 Altick R. The shows of London. Cambridge, Massachusetts: Harvard Universion Press, 1975.

4 Hone W. Every day book. Vol I. London: Hunt and Clarke, 26 July 1828 N 1017-34.

5 Ravitch MM. Disorders of the chest wall. In: Sabiston DC, ed. The textbook of surgery - the biological basis of modern surgical practice. Philadelphia: Saunders $1986,2080-3$.

6 Sprengel OGK. Die angeborene Verschiebung des Schulterblattes nach oben Archiv Klinische Chimurgi 1891;42:545-9.

7 Jeannopoulos CL. Congenital elevation of the scapula. $\mathcal{J}$ Bone foint Sung 1952;A34:883-92.

$8 \mathrm{Klippel} \mathrm{M,} \mathrm{Feil} \mathrm{A.} \mathrm{Anomalie} \mathrm{de} \mathrm{la} \mathrm{colonne} \mathrm{vertebrale} \mathrm{par} \mathrm{absence} \mathrm{des} \mathrm{vertebrasu}$ cervicales-cage thoracique remoutant jusqu'à la base du crane. Bulletiñ Société Anthropologie, Paris 1912;65:101-5.

9 George MD. Catalogue of personal and political satires preserved in the department prints and drawings in the British Museum. Vol X. 1820-1827. London: British Museum, 1952:527.

10 Living skeleton. Lancet 1825;viii:178-9.

11 De Arenas MN. Manojo de noticias-la suerte de Goya en Francia. Bulletw Hispanique 1950;52:229-73.

\title{
The Keppel Club (1952-74): lessons from the past for the future
}

\section{John Fry}

The Keppel Club was a think tank with an influence beyond its size because of its membership and format. It remains an educational model for cross fertilisation of ideas. The club was the brain child of John Brotherston and his colleagues at the London School of Hygiene and Tropical Medicine. Why "Keppel"? Because the school is the only address in Keppel Street - a short street of. less than 100 yards facing the Senate House of the University of London and connecting Gower Street with Malet Street.

A radical group of young lecturers came together at the school in the early 'fifties. It was the aftermath of the second world war and the start of the NHS. It was a time of confidence in a bright future for health care in Britain, and young men and women believed in themselves and in their abilities and opportunities to fashion a new and better health system.

John Brotherston was a senior lecturer at the school and he believed that there was a need for a small group to meet, talk, and plan for the future. The club met for the first time on 20 March 1953, and from then until 1974 it met 140 times.

It was a small and informal club with an average attendance of between 10 and 20 . The meetings were monthly, during term time, on a Friday from $530 \mathrm{pm}$ to $730 \mathrm{pm}$ followed by more informal discussion at a local pub. An invited speaker opened with a 15 to 20 minute introduction, which was followed by a wide ranging discussion. A report was prepared by the secretary and circulated with a notice for the next meeting.

\section{Intentionally small}

The club was intentionally small. During its 22 years there were never more than 25 members at any times and in all there were 50 who came and went. The air was a membership that was wide ranging in ideas and experience. Although members were formally electect at a club meeting, the process of selection was informa Individuals with original ideas and who were likely stimulate were suggested; they were invited to one of more meetings as visitors, and then elected. Persona knowledge and quality of publications were much more important than ex-officio appointments by virtue of positions held at the London School of Hygiene ô. elsewhere.

Although most members were originally Londow based, many continued as less regular attenders as the moved away. The secretary's reports of each meeting sent to all members were much appreciated by countig members as sources of contact, information, and education.

\section{How was influence effected?}

Although it is impossible to measure objectively, influence of the club was most probably through the informal and friendly rubbing of shoulders and the introduction of free wheeling thoughts and ideas prof moted by uninhibited discussion. The club's succes was partly due to the climate of opportunity in an evolving NHS, with the opportunities to test and develop new methods and systems, but also to the 


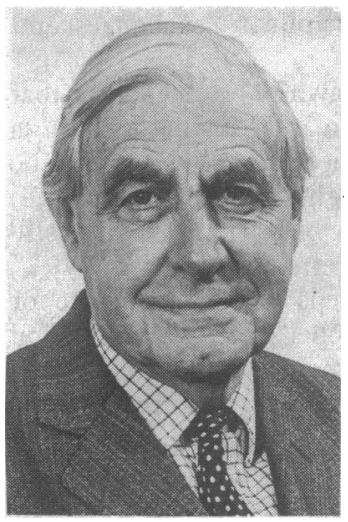

Lord Taylor interdisciplinary nature of the membership, which extended well outside clinical practice.

- John Brotherston took some of the club's suggestions to Scotland and as chief medical officer and professor of public health he encouraged the Livingston New Town experiment with joint general practice and hospital appointments.

- Stephen Taylor's work at Harlow with the model health centres, his book Good General Practice, and his activities in the House of Lords were likely to have been influenced by the club's discussions.

- In their pioneering work in developing better care for children in London. Guy Wigley and Ronald MacKeith must have been heartened by the warm support of club members.

- Richard Titmuss, Brian Abel-Smith, Sandy Robertson, and Chris Wood brought to and took from the club international and global viewpoints.

Sadly, the late Nic Malleson's proposals for a new school of human biology were too far ahead of their time, but now, some 30 years later, many of their ingredients have been accepted.

\section{Personal reminiscences}

TOM ARIE

Tom Arie joined the club in 1964 as a young lecturer when the "young lecturers" of the 1950 s were no longer so young. He was the first lecturer in social medicine in London University. In those days it was still permissible to find it exciting to sit at the feet of great men, and Tom remembers the excitement of meeting and talking on equal terms with such people. In the latter half of the 1960s it was thrilling to discuss issues with people who were often at the centre of events. The expansion of higher education was in the air. Everyone was discussing new medical curriculums and new medical schools. London teaching hospitals were in the process of becoming district hospitals. Robbins had reported on higher education and so had the Royal Commission on Medical Education in 1968. New ideas were around and there were resources to implement them.

In 1969 Tom Arie moved from the London Hospital to set up one of the earliest psychiatric services for old people in a large mental hospital in Ilford. Many colleagues were astonished that anyone should choose the combination of old age, mental illness, and a mental hospital. Indeed, for the first year Tom thought he might have taken leave of his senses.

It was at the Keppel Club that the Goodmayes psychiatric service for old people was first described, and the first year's work offered for discussion and criticism by colleagues. The members of the club were enthusiastic, and Tom went away that evening feeling that it was going to be all right. Notes and postcards after the meeting were full of encouragement. Sir George Godber was not present but read the minutes and sent his chief psychiatrist, Arthur Oldham, to take a look at Goodmayes - thereby establishing the beginning of the links with the Department of Health.

Old age psychiatry is now an official specialty in the NHS and is recognised as an important discipline here and abroad. Tom Arie sometimes wonders what direction he might have taken professionally had the Keppel Club given the thumbs down that evening.

\section{JOHN FRY}

In the 1950s I was in singlehanded general practice and had decided that, as I knew little about it and as there was nowhere to turn to, I had to collect data to discover what I was doing, how, and with what results - a minor voyage into audit.

I knew nothing about research methods and had

\section{Keppel Club members}

Brian Abel-Smith, London School of Economics Roy Acheson, Yale and Cambridge Universities Tom Arie, Goodmayes Hospital and later University of Nottingham

Jock Anderson, Guy's Hospital

Maurice Backett, Universities of Aberdeen and Nottingham

John Brotherston, Scottish chief medical officer

Ann Cartwright, Institute of Community Studies

Peter Draper, Guy's Hospital

John Faulkner, Medical Research Council

Charles Fletcher, Hammersmith Hospital

John Fry, general practitioner, Beckenham

George Godber, later chief medical officer at the Ministry of Health

Bob Haggerty, Harvard University

Walter Holland, St Thomas's Hospital

Margot Jefferys, Bedford College

John Last, Edinburgh and later Ottawa

Harry Levitt, general practitioner, north London

W P D Logan, chief medical statistician at the General Register Office

Ronnie MacKeith, paediatrician, Guy's Hospital

Stephen MacKeith, psychiatrist, Warlingham Park Hospital, Croydon

Nic Malleson, Student Health Service, University of London

Jerry Morris, London Hospital and London School of Hygiene and Tropical Medicine

John Osborne, general practitioner, West London

Sandy Robertson, Milbank Memorial Fund and

World Health Organisation

Michael Shelpher, Institute of Psychiatry

Stephen Taylor (later Lord Taylor)

Richard Titmuss, London School of Economics

Peter Townsend, London School of Economics

Michael Warren, University of Kent

Guy Wigley, London County Council

Albertine Winner, Ministry of Health

Christopher Wood, Tanzania

no research tools. It was all paper and pencil study. I had started to write and the editor of the $B M \mathcal{F}$, Hugh Clegg, had published some of my papers. I presume that because of these I was invited to join the club.

From the discussions I became more familiar with data collection and application. I was able to pose questions and test some hypotheses. Above all, I became aware of the integrated nature of the NHS and the essential role of primary health care. I was encouraged to travel and realised that primary health care was necessary and inevitable in all national health systems and that almost by chance and default general practice in the NHS potentially had the best structure and opportunities for efficient, effective, and economic care and service.

I soon realised that my colleagues in the club knew almost nothing of the structure, nature, contents, and needs of general practice. My comments and contributions enlightened and amused them.

My contacts with W P D Logan facilitated the first national morbidity surveys; and those with Charles Fletcher led to the College of General Practitioners' study into chronic bronchitis and the first use of the Wright peak flow meter. It was at the club that I firs met George Godber and John Brotherston, whose support over the years proved so helpful.

\section{What were the issues considered?}

The original aims were for the club to meet and discuss "problems of medical care," which were gradually widened to include "social medicine" and "health care."

The subjects were selected by the chairman, secre- 


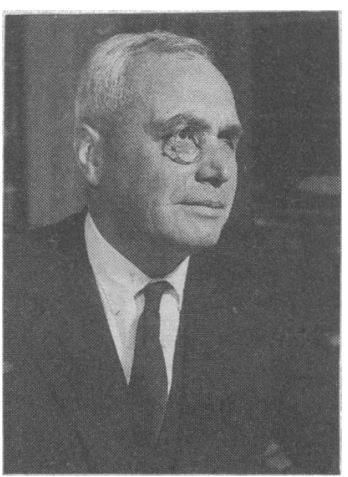

Sir George Godber tary, and club members. Over the 22 years they included care of the aged, adolescence, school health services, child health, occupational health, hospital services, general practice, costs of the NHS, future of mental hospitals, collection and use of data in the NHS, social aspects of obstetrics, and medical care in other countries. Government reports were analysed and debated, as were hospital plans, perinatal mortality surveys, medical education, and empathy with and care of patients. There were never any publications from the club, but the private discussions must have initiated many by individual members.

\section{Looking back and forward}

The club died in 1974 because there was no young generation of leaders ready to take up the baton. Times have changed; there is now more sophistication and specialisation and less time for social medicine involving informal, interdisciplinary exchanges and discussions.

But what lessons can be drawn? The chief one is that the best continuing education and learning is through the stimulus of the regular meeting of like minds who are prepared to let their thoughts run free and wide. It may be an old fashioned way of learning but it is still one of the best and most cost effective.

Another lesson is that there is a time and a place for specific initiatives. The Keppel Club was right and relevant for its times and its members. It ceased partly because most of its original members had reached the stage when they had no longer the time, energy, or need for it. Surely with the radical changes now taking place in the NHS the time has come for a new generation to set up new Keppel Clubs?

I should like to thank Margot Jefferys for advice and comments and Tom Arie for his contribution.

\section{BASIC MEDICINE}

\section{Seeing for themselves}

\author{
M J Kelly
}

Why do $5 \%$ of candidates fail the final $\mathrm{MB}$, and why do about half of these fail it so badly? After all, they had mostly AAA or ABB grades at A level. My attendance at examiners' meetings over the past seven years in Bristol, Leicester, and Cambridge strongly suggests that although marginal failures can result from many factors (unlucky on the day, a couple of bad errors, mind too occupied with matters non-medical), the bad failures uniformly seem to attract the comment, "Don't think he/she really wants to become a doctor!"

Sometimes such men or women are sent to our surgical firm for "remedial teaching" to "get them through the finals next time." So I have talked with them - and found myself in quite a dilemma regarding whether it is in their best interests that I should be attempting this conjuring trick (on their behalf) or not.

I believe that this is what happens: the teacher sees a bright, but uncommitted, science sixth former and encourages his or her application to medical school on the grounds that the child is not overtly hostile, medicine is a very secure career, socially it is highly acceptable, and acceptance will add kudos to the school, the child, and the teacher. Armed with good A levels (say AAB) and supported by a suitably glowing testimonial from the head teacher (which, with the alteration of but a word or two, might equally well have supported an application to law school, an engineering course, or a merchant bank) the child is accepted to become a doctor, perhaps without interview.

On arrival at medical school students start by dissecting cadavers preserved in formalin and are required to master an excess of biochemical trivia learned by rote. Most accept this cultural shock stoically: if doubts do surface the students are frequently reassured that although the preclinical course may seem dull, "The hospital will be completely different - and wonderful!"

Because they are $A A B$ people, they pass the examination (which is very like an $\mathrm{A}$ level) and arrive on the

\begin{abstract}
Dangers of the scheme
There was much heart searching after one lad went out like a light while talking to me and landed with a tremendous crash on the theatre floor, sustaining moderate concussion. We discovered that his parents were abroad for the week; so, skull $x$ rays were taken and he was admitted overnight, while many telephone calls were made. I personally felt terribly guilty, with visions of a trip to the neurosurgeons, burr holes, and the rest. However, he was fine by the next morning, and I received great support from colleagues, especially the district medical officer and the unit general manager; they pointed out that everything possible had been done to avoid this happening. The school authorities were also used to this sort of thing and took it in their stride, with the boy's form master coming to visit him in hospital that evening. A full recovery followed-and the boy wants to be a surgeon.
\end{abstract}

wards, where they feel just as out of place. Should they complain now, they will be told that it is "Too soon to tell!" Thus, one way and another, it may be only by the start of their final year, when they really can perceive the shape of the way that lies ahead, that they pluck up the courage to tell someone that they cannot imagine what they are doing here at medical school, and that they don't want to qualify, or to be a doctor.

By now the argument runs: "Well, this may be so, but it seems a pity to throw away five or six years of endeavour: at least go on and take your medical degree." So some do; but it is then no use having it unless you have completed the year as a house officer to permit full registration. Thus, only when they are 23 or 24 years old will we all admit that these students should have changed course long ago. Other students find it impossible to settle down to study in order to achieve the MB passport to a career they no longer wish to embrace. 